\title{
ANALISIS KONSEP DASAR ISLAM PADA PEMBELAJARAN SAINS DI MADRASAH IBTIDAIYAH KELAS IV (FISIKA \& BIOLOGI)
}

\author{
Dibrina Raseuki Ginting, Syafira Aini Beru Ginting, Zikraul Husna, \\ Veni Veronika Siregar, Nurul Aflah
}

Surel: 20204081010@ student.uin-suka.ac.id

\begin{abstract}
The concept of learning that is arranged in the world of education is veryinfluential in order to arrive at the goals that have been determined. The application of learning must be structured in such a way that the expected learning process runs. The Learning Process Design (RPP) is a benchmark for aneducator when carrying out learning, the RPP that is formed must have conformity to the learning content carried out by the educator and here the author designs a lesson planforclass $I V$ Madrasah Ibtidaiyah. The writing method uses a literature review of severaltrusted sources of scientific articles. The results obtained in this paper are the implementation of the basic concepts of Islam in Science subjects (Physics and Biology) which in the lesson plans are developed materials that combine Science subjects with religious science and combine the two, so that students arenotonly required in the cognitive domain but students also know Science from spiritual aspect and being able to be grateful for what they have and can apply the meaning of the verse that has been written in the Qur'an Surah Al-An'am: 99 teacheshumans about the natural resources that God has given to humansand how to manage them.
\end{abstract}

Keywords: Basic Concepts of Education, Science Learning, Madrasah Ibtidaiyah

\begin{abstract}
ABSTRAK
Konsep pembelajaran yang disusun dalam dunia pendidikan sangat memiliki pengaruh guna sampai pada tujuan yang sudah ditentukan. Pengaplikasian pembelajaran haruslah disusun sedemikian rupa guna berjalannya proses pembelajaran yang diharapkan. Rancangan Proses Pembelaran (RPP) menjadi tolak ukur bagi seorang pendidik ketika melaksanakan pembelajaran, RPP yang dibentuk harus memiliki kesesuaian terhadap muatan pembelajaran yang dilaksanakan oleh pendidik dan disini penulis merancang sebuah RPP pada kelas IV Madrasah Ibtidaiyah. Metode penulisan menggunakan kajian pustaka terhadap beberapa sumber artikel ilmiah yang terpercaya. Hasil yang didaptkan dalam penulisan ini adalah implementasi konsep dasar Islam pada matapelajaran Sains (Fisika dan Biologi) yang didalam RPP tersebut dikembangkan materi yang menggabungkan matapelajaran Sains dengan ilmu agama serta mengkombinasikan keduanya, sehingga siswa tidak hanya dituntut pada ranah kognitif tetapi siswa juga mengetahui Sains dari segi spiritual dan dapat bersyukur atas apa yang dimiliki serta dapat mengaplikasikan makna ayat yang sudah tertera pada Al-Qur'an Surah Al-An'am: 99 mengajarkan kepada manusia mengenai SDA yang diberikan Allah kepada manusia serta bagaimana cara mengelola hal tersebut.
\end{abstract}

Kata Kunci: Konsep Dasar Pendidikan, Pembelajaran Sains, Madrasah Ibtidaiyah 



\section{SCHOOL EDUCATION JOURNAL VOLUME 11 NO. 4 DESEMBER 2021}

\section{PENDAHULUAN}

Pengajaran dalam Islam Pengajaran dalam pelajaran Islam merupakan sesuatu yang sangat diharuskan dan merupakan kebutuhan esensial yang harus dicari dan dirasakan oleh setiap individu. Dalam pelatihan seperti itu, tidak cukup hanya memberikan materi pembelajaran yang diatur untuk dunia saja, namun juga harus diimbangi dengan ilmu pesantren. karena Allah SWT menasihati kita untuk menyesuaikan di antara keduanya, baik keberadaan dunia ini maupun keberadaan hal di luar dunia. Seperti yang diungkapkan dalam hadits yang diuraikan oleh Ahmad, secara spesifik:

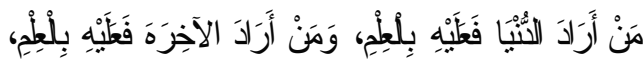

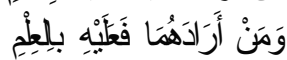

"Barangsiapa yang hendak menginginkan dunia, maka hendaklah ia menguasailmu. Barangsiapa menginginkan akhirat, hendaklah ia menguasai ilmu. Danbarang siapa yang menginginkan keduanya (dunia dan akhirat), hendaklah ia menguasai ilmu." (HR. Ahmad)

$$
\text { Di sekolah, penting untuk }
$$
menanamkan standar tauhid dalam pendidikan ilmu-ilmu umum termasuk ilmu pengetahuan. Pemahaman pelatihan Islam dalam pembelajaran sains (IPA) disimpulkan dalam Alquran. Alquran tidak menyangkal sains dan agama. Memang, bahkan di sejumlah besar bagian-Nya, digarisbawahi bahwa orang harus secara konsisten mempertimbangkan kejadian di alam untuk memperkuat keyakinan ketat mereka ditemukan dalam Q.S. AlAnbiyaa pasal 30 yang mengandung arti "Dan apakah orang-orang yang kafir tidak mengetahui bahwasanya langit dan bumi itu keduanya dahulu adalah suatu yang padu, Kemudian kami pisahkan antara keduanya. dan dari air kami jadikan segala sesuatu yang hidup. Maka mengapakah mereka tiada juga beriman?" (D.A, 2002). Mengingat syair di atas, sangat mungkin terlihat bahwa sains dan agama adalah satu kesatuan logis yang kompleks. Manusia diberi motivasi oleh Tuhan untuk membedah dan memeriksa apa yang ada di alam sebagai latihan bagi orangorang bahwa pelatihan mengambil bagian penting dalam keberadaan dan perkembangan manusia.

\section{METODE PENELITIAN}

Penulisan Penulisan ini menggunakan kajian pustaka. Menurut Mirzaqon dan Purwoko Metode penelitian kepustakaan atau Library Research merupakan penelitian teori, bahan referensi dan kajian lainnya terkait nilai sosial diteliti (A \& B, 2018). Menurut Khatibah yang dikutip oleh Milya Sari penelitian perpustakaan adalah suatu kegiatan mengumpulkan, proses, dan ringkas informasi secara sistematis memakai cara tertentu untuk menemukan solusi terhadap pertanyaan Tantangan yang dilewati saat melalui kajian perpustakaan (M, 2020).

Berdasarkan hal tersebut, maka pengumpulan data dalam artikel ini 
Dibrina Raseuki Ginting, Syafira Aini Beru Ginting, Zikraul Husna, Veni Veronika Siregar, Nurul Aflah : Konsep Dasar islam ...

dilakukan dengan cara menelaah serta review beberapa referensi, seperti buku, Jurnal ilmiah yang telah tersinta, laporan penelitian (skripsi), serta bahan tertulis percetakan dan elektronik dan penelitian lain yang lebih relevan

\section{HASIL PENELITIAN DAN PEMBAHASAN \\ Konsep Dasar Pendidikan Islam}

Pada dasarnya, gagasan pelatihan Islam menggabungkan setiap tujuan instruktif. Pelatihan Islam adalah ide tunggal dari sekolah yang membuat signifikansi dan motivasi di balik pengajaran lebih tinggi sehingga membimbing orang ke visi yang ideal dan membuat individu jauh dari pengabaian dan penyimpangan $(B$, 2017). Gagasan pengajaran sebagaimana diindikasikan oleh sudut pandang Islam harus disinggung dalam berbagai perspektif, termasuk sudut pandang yang tegas, sudut pandang bantuan pemerintah, sudut fonetik, sudut pandang ruang lingkup, dan sudut kewajiban (Nasution, 2014). Pengaturan ini mengandung makna bahwa bagaimana keterkaitan Islam dalam ajaran dan kehidupan sehingga bisa menjadi sumber informasi di ranah pelatihan.

Menurut Hasan Langgulung, dalam Usman premis operasional pendidikan Islam dibedakan menjadi enam hal, yaitu yang bersifat kronik, sosiologis, moneter, politis dan manajerial, mental, dan filosofis, yang keenam hal tersebut berpusat pada premis filosofis (Usman,
2017). Senada dengan hal tersebut, Abdul Mujib dan Jusuf Muzakir menambahkan, penjaminan dasar tersebut harus menambah dasar yang tegas dalam kegiatan pembinaan. Ini atas dasar bahwa Islam menuntun agama sebagai sebuah dasar, karena agama adalah ujung tombak dari setiap gerakan Islam (Mujib \& Muzakir, 2008). Dengan agama, semua amalan instruktif menjadi penting, memiliki nada dasar lain, dan memiliki nilai-nilai ubudiyah. Sehubungan dengan hal tersebut, penyelenggaraan Pendidikan Islam memiliki tujuh perspektif yang perlu diperhatikan, termasuk bagian dari agama.

- Dasar Historis

- Dasar Sosiologi

- Dasar Ekonomi

- Dasar Politik dan Administratif

- Dasar Psikologi

- Dasar Filosofis

- Dasar Relegius

\section{Pendidikan Islam Dalam Pembelajaran Sains}

Mempelajari sains menurut Islam bukanlah sesuatu yang baru, hal ini dengan alasan bahwa Islam telah mengkaji sains beberapa waktu sebelum para pencipta logika mengenalkan sains kepada manusia. Pemahaman ajaran Islam dalam pembelajaran sains (IPA) disarankan dalam al-Qur'an. Al-Quran telah mengungkap banyak realitas yang terkait dengan sains itu sendiri. Sejujurnya, dalam sejumlah besar ayat- 


\section{SCHOOL EDUCATION JOURNAL VOLUME 11 NO. 4 DESEMBER 2021}

Nya digarisbawahi bahwa orang-orang secara konsisten menganggap peristiwaperistiwa di alam untuk membentengi keimanan mereka yang ketat sehingga individu-individu mengetahui pentingnya Allah SWT. Seperti yang tertuang dalam Q.S. Al-Furqan bagian 53 :

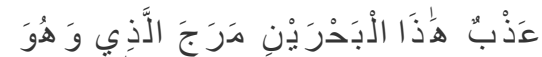

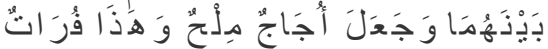

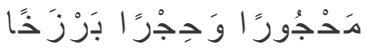

"Dan Dia (juga) yang mengalirkan kepada laut (yakni sungai dan lautan) yang ini tawar lagi lezat dan yang ini asin lagipahit. Dan dia telah menjadikan diantara keduanya pemisah dan pembatas yang tersembunyi yang tidak dapat dilihat...." (Q.S Al-Furqan : 53) (D.A, 2002).

Mengingat bagian di atas, tidak salah lagi Allah telah memerintahkan dan mengungkapkan kepada orangorang tercantum di Al-Qur'an bermakna Allah sehubungan dengan air laut dan saluran air yang tidak dapat digabungkan beberapa waktu sebelum para peneliti logis menyelidiki tentang air laut. dan aliran yang tidak bisa bercampur. Selain itu, klarifikasi logis dari bagian tersebut pada buku Selekta dari Tafsir: Ayat Kosmis dalam AlQur'an Al Karim ditulis Zaghloul ElNaggar yang dikutip oleh Amiruddin menjelaskan bahwa jika tidak Allah merencanakan aliran ke air yang layak dengan tekanan tinggi. Dari faktor laut yang tidak terduga, maka mengosongkan air tawar yang mengandung endapan lumpur ke lereng dengan garam pasti akan mengantar air laut akan menggenangi daratan, juga air tawar, akhirnya benar-benar melenyapkan juga memusnahkan semua yang ada di darat (MS, 2018). Sungguh Allah telah mengatur kehidupan sebaik yang diharapkan.

Untuk situasi ini, sains sama sekali bukan bagian agama yang berbeda dengan tanda yang sama. Sains adalah bagian penting dari Islam. Sains menunjukkan kepada orang-orang bagaimana mengawasi alam, menyelesaikan berbagai siklus, dan menghasilkan sesuatu untuk kebutuhan hidup. Sementara itu, agama menunjukkan kepada orang-orang kerangka nilai itu sendiri. Agama mendidik tentang nilai komitmen terhadap Khaliq dan nilai kemurahan hati kepada orang lain.

Latihan pembelajaran sains (IPA) lebih terkoordinasi dengan latihan yang mendorong siswa untuk beradaptasi secara efektif. Dalam memilih pendekatan pembelajaran IPA di SD / MI, pendidik secara konsisten memikirkan kantor sekolah saat ini. Ada beberapa metodologi yang dapat dipertimbangkan dalam menyelesaikan penjemputan. Terlepas dari metodologi ini, ada cara untuk mengatasi penemuan yang secara umum akan integratif dalam memandang suatu masalah, menggunakan pendekatan SETS ditambahkan ke perspektif Islam yang ketat dan yang berpangkal pada AlQur'an serta Sunnah Nabi.

Dalam sudut pandang yang luas, sains bukan sekadar informasi yang 
Dibrina Raseuki Ginting, Syafira Aini Beru Ginting, Zikraul Husna, Veni Veronika Siregar, Nurul Aflah : Konsep Dasar islam ...

mengandung realitas, gagasan, dan standar, tetapi pada saat yang sama dipandang sebagai interaksi yang efisien. Ilmu adalah mata pelajaran yang mengkaji alam, seperti tumbuhan, makhluk, protes, dll. Dimana alam semesta ini adalah ciptaan Allah SWT. Seperti halnya Al-Quran surah AlAn'am pasal 99:

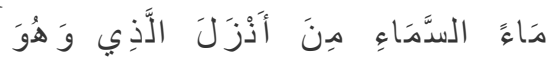

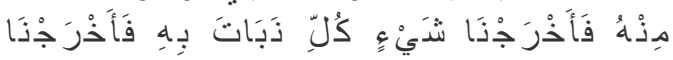

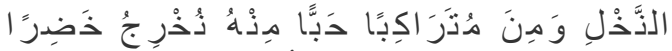

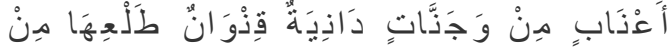

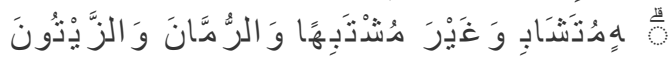

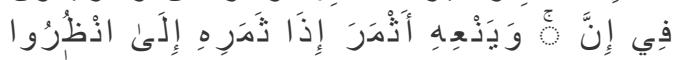

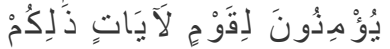

Artinya: "Dan Dialah yang menurunkan air hujan dari langit, lalu Kami tumbuhkan dengan air itu segala macam tumbuh-tumbuhan maka Kami keluarkan dari tumbuh-tumbuhan itu tanaman yang menghijau... (Q.S AlAn'am: 99)" (D.A, 2002).

Akibatnya bagaimana Allah mendalangi kerangka eksistensi manusia dalam Al-quran dan manusia perlu menemukan lebih banyak dan mencari tahu bagaimana ilmu terhubung dalam sudut pandang Islam. Ini juga dibangun oleh Quraish Shihab yang berpendapat bahwa beberapa kali bait Al-Qur'an menerangkan keajaibannya untuk dikenang terhadap kelas inovasi dan bagaimana menerapkan sains untuk menggunakan alam untuk bantuan pemerintah manusia dan penghiburan (Indra, 2009).

\section{Implementasi \\ Integrasi Pembelajaran Sains (Fisika dan Biologi)}

- Fisika

Gerakan mendorong atau menarik membuat benda bergerak dikenal sebagai kekuatan. Kekuatan yang diterapkan disebuah item akan mempengaruhi artikel itu. Kekuatan diartikel bisa menyebabkan item yang awalnya sangat diam kemudian berpindah, menjadikan artikel yang awalnya beralih menjadi bergeser bantalan, serta mengubah status item. Misalnya, saat Anda memukul bola, bola akan bergerak dan bergeser arah. Sedangkan ilustrasi mengubah keadaan artikel karena dampak kekuatan adalah ketika Anda bermain dengan plastisin, seseorang mampu menciptakan wujud yang berbeda. Keahlian seorang dalam menciptakan membuat bentuk plastik ideal.

Daya tarik yaitu gaya yang dapat menarik jarum, paku atau benda lain yang terbuat dari besi atau baja, dan ini dikenal sebagai daya tarik.

Gambar 1. Magnet menarik benda (paku)

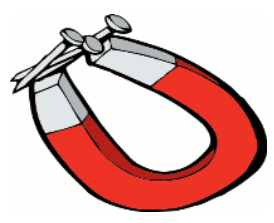

Sumber: https://lindadarra.wordpress.com 
Daya listrik dihasilkan melalui gesekan serta digerakkan oleh barang bermuatan listrik guna menarik barang di sekitarnya, kita mampu melakukan pemeriksaan demi mendemonstrasikan adanya daya listrik statis. Berikan penggosok rambut sedikit rambut dan kemudian atur kertas sudah digunting hancur, kemudian menggosoknya berkali-kali ke rambut, bawa penggaris/rol lebih dekat ke potongan/guntingan kertas, lalu Anda akan melihat potongan-potongan kertas. kertas ditarik ke arah penggaris/rol, tenaga listrik berbasis gesekan.

\section{Gambar 2. Gaya penggaris menarik} sobekan kertas

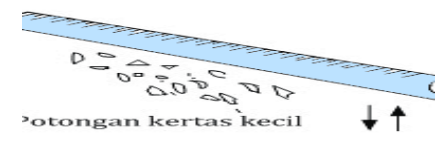

Sumber:https://www.gudangpustakailmu. me/

Kekuatan otot adalah kekuatan yang diperoleh dari otot manusia.. Jika seorang berolahraga, otot menjadi lebih kuat serta lebih membumi.

\section{Gambar 3. Gaya dorong dan gaya tarik}

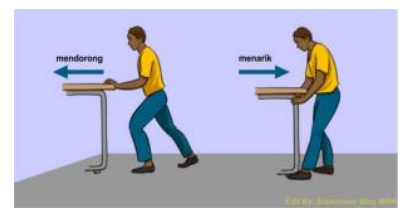

Sumber : https://www.fisikabc.com
Kekuatan gravitasi bumi yakni menarik benda-benda yang berbeda ke bawah. Seperti halnya, melempar suatu barang lain ke atas, maka barang pasti jatuh(ke bawah) karena tarikan gravitasi bumi atau mungkin juga dikenal sebagai kekuatan gravitasi dunia (Istisaroh, 2017).

\section{Gambar 4. Buah apel yang jatuh dari pohonya}

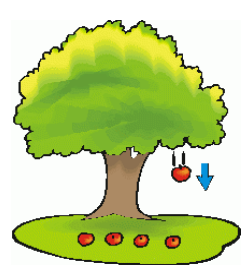

Sumber :

http://sunankalijaga indah.blogspot.com

Daya pegas adalah daya yang diciptakan oleh elastis atau pegas yang diperpanjang. Contohnya saat Anda main-main toksofilisme, karetelastis dapat melemparkan baut terlempar jauh dan cepat.

Gambar 5. Gaya tarikan anak panah

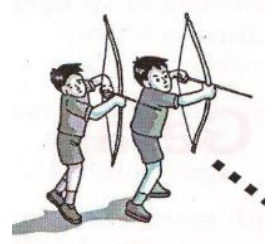

Sumber: https://kurniatria.wordpress.com

a) Gaya Gesek Antara Dua Benda

Kekuatan gesek adalah kekuatan yang terjadi ketika dua permukaan bersentuhan dengan sebuah benda. Gambaran kisi-kisi adalah tenaga yang mengikuti rem sepeda, saat elastis rem 
Dibrina Raseuki Ginting, Syafira Aini Beru Ginting, Zikraul Husna, Veni Veronika Siregar, Nurul Aflah : Konsep Dasar islam ...

pada sepeda akan bersentuhan dengan boks sepeda sehingga terjadi gerinda yang membuat sepeda berhenti saat direm (Istisaroh, 2017).

\section{Gambar 6. Pengereman sepeda}

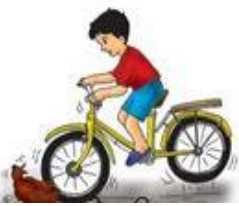

Sumber : http://istisaroh409.blogspot.com

Gerak Gerakan adalah penghapusan situasi suatu item terhadap artikel lain, karena kekuatannya. Misalnya, saat kita lari, akan terjadi pencabutan, seseorang berpindah mulai dari posisi semula lalu ke posisi berikutnya. Sifat-sifat gerakan meliputi (Istisaroh, 2017):

- Barang-barang pada umumnya akan bergerak secara tertib. Model: sebutir kelapa tumbang dari pohon, langsung tumbang.

- Elemen yang mempengaruhi pergerakan artikel

- Bentuk Objek: Keadaan benda berubah, persegi, segitiga. Keadaan barang mampu mempengaruhi pergerakannya. Seperti halnya ban sepeda bisa berpindah tanpa masalah. Artikel bundaran lebih sederhana untuk dipindahkan daripada bentuk lain.

- Ukuran Objek: Skala sebuah barang bias menangkap kekuatan, misalnya bola kaki lebih besar dari bola ping pong, maka di sepanjang garis ini bola ping pong lebih mudah untuk digerakkan daripada bola kaki.

- Permukaan Objek: Bagian luar item tidak menyenangkan juga lembut. Jenis permukaan artikel bias mempengaruhi suatu item. Barang dengan permukaan halus lebih mudah dipindahkan daripada barang dengan permukaan yang tidak bagus. Karena permukaan yang tidak menyenangkan memiliki daya erosi yang lebih menonjol daripada permukaan yang halus. Semakin tidak menyenangkan bagian luar sebuah artikel, semakin merepotkan item tersebut untuk bergerak, dan sebaliknya. Model: sepeda di jalanan yang kosong lebih mudah untuk digerakkan daripada berjalan di permukaan yang kasar (Riski, 2017).

\section{Pengaruh Gaya Terhadap Pergerakan Benda}

Kekuatan dapat mempengaruhi pergerakan barang. Sebagian dari dampak kekuatan pada pergerakan barang adalah:

a) Kekuatan dapat mempengaruhi item tetap ke dalam gerakan.

b) Kekuatan dapat mempengaruhi barang yang bergerak untuk tetap terpasang.

c) Kekuatan dapat mempengaruhi jalannya pergerakan suatu barang.

d) Kekuatan dapat memengaruhi objek yang bergerak lebih cepat atau lebih lambat. 


\section{SCHOOL EDUCATION JOURNAL VOLUME 11 NO. 4 DESEMBER 2021}

Hubungan antara gaya dan gerakan dan hubungannya dengan kejadiankejadian di iklim.

a) Hubungan antara kekuatan dan gerakan jika memainkan umban dan mengirimkannya mempengaruhi batu yang awalnya diperbaiki untuk bergerak setelah dilempar menggunakan peluncuran.

b) Hubungan antara tenaga dan gerak dalam pembuatan gerabah adalah gaya yang dilakukan oleh para ahli saat membingkai lumpur, mengubah keadaan kotoran menjadi periuk.

c) Keterkaitan antara tenaga dan gerak dalam hal mencungkil adalah kekuatan yang digunakan paman saat menarik tali ember, menyebabkan wadah yang masih sangat tinggi itu terangkat (Info Dunia Edukasi, 2020).

\section{Hubungan Materi Gaya dan Gerak Dalam Islam}

Materi Islam telah mengajarkan dalam ayat Al-qur'an bahwa untuk merubah sesuatu keadaan dimulai dari diri sendiri. Perubahan yang dimaksud secara tegas Allah SWT berfirman dalam Q.S Ar-Ra'd ayat 11 yaitu :

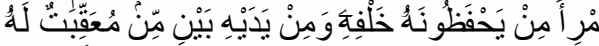

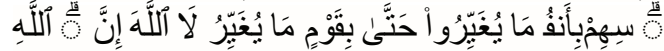

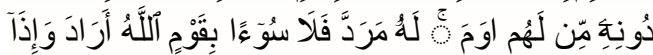
(Qَالٍٍ مِن (QS Ar-Ra'd : 11) (D.A, 2002).

Penggabungan syair ke dalam materi, corak dan gerak, adalah bahwa Allah SWT dan dapat mengubah takdir, segala hal yang dipertimbangkan, dan semua kelompok orang. Sekalipun demikian, hidup ini adalah keadaan yang masuk akal. Ini sama saja dengan soal kekuasaan dan gerak di mana benda tidak mau bergerak jika tidak terkena paksaan, menurut materi ayat Alquran, hidup tidak akan bergerak dan tidak maju. jika tidak menggunakan daya atau diubah.

- Biologi

Sumber karakteristik adalah semua kelimpahan sebagai makhluk tak bernyawa atau makhluk hidup bias dipakai guna mengatasi masalah keberadaan manusia. Semua yang ada di alam (di luar orang) dianggap memiliki kemudahan untuk mengatasi masalah sehingga bantuan pemerintah yang manusiawi dilakukan.

SDA biasa adalah istilah yang diidentikkan dengan materi dan kemungkinan normal yang ada di planet bumi yang memberikan keuntungan bagi keberadaan manusia. Material biasa dapat melalui makhluk hidup (komponen hidup), khususnya makhluk dan tumbuhan, dan ada juga benda mati (tidak hidup) seperti tanah, udara, air, mineral atau hasil tambang.

Ada beberapa macam jenis-jenis SDA yang bisa dimanfaatkan, berikut klarifikasi jenis-jenis SDA pada gambar berikut: 
Dibrina Raseuki Ginting, Syafira Aini Beru Ginting, Zikraul Husna, Veni Veronika Siregar, Nurul Aflah : Konsep Dasar islam ...

\section{Gambar 7. Bagan Pembagian Jenis Sumber Daya Alam}

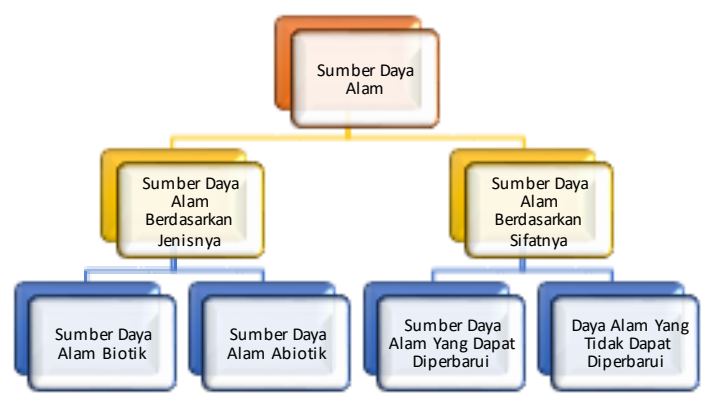

Sumber : (Subekti, 2013)

\section{Hubungan Materi Sumber Daya Alam Dalam Islam}

Islam telah mengajarkan pada ayat Al-qur'an bahwa semua yang sudah ditetapkan Allah baik itu dilangit maupun dibumi merupaka sumber nikat bagi manusia hal ini dengan jelas Allah SWT berfirman dalam Q.S Al-Baqarah ayat 29 yaitu :

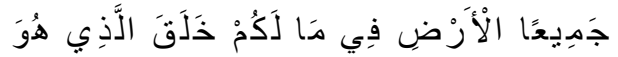

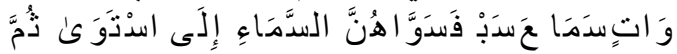

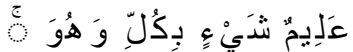

Bagian di atas memperjelas bahwa segala hal ada di dunia juga di langit kepunyaan Allah berada pada seluruh harta kekayaan yang dapat dinikmati dan diawasi oleh manusia demi kelangsungan eksistensi manusia itu sendiri. Harta kekayaan yang melimpah dapat dimanfaatkan sebaik yang diharapkan, baik sebagai tumbuhan ciptaan Allah, ikan di lautan dan berbagai hal lainnya. Terlebih lagi, Allah juga memerintahkan manusia untuk mengamankan harta benda biasa yang ada di bumi, bukan memusnahkan semua yang telah Allah berikan kepada manusia sebagai anugerah yang tak terhitung banyaknya. Seperti yang dikatakan Allah dalam surah Ar-Rum refrain 41, secara khusus:

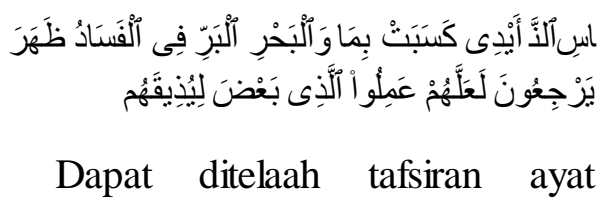
tersebut menerangkan bahwa sudah banyaknya kehancuran yang timbul dibumi diakibatkan ulah manusia itu sendiri, manusia tanpa sadar merusak alam yang dampaknya bagi manusia itu sendiri.

\section{SIMPULAN}

Pendidikan Islam adalah dorongan untuk menumbuhkan temperamen anak secara umum untuk mencapai karakter yang telah ditentukan sebelumnya. Dengan cara ini, Pendidikan Islam mendorong fitraah anak muda dalam arti luas yang mencakup dunia lain, perspektif, informasi dan menciptakan kemampuan potensial yang digerakkan oleh anak-anak dan orang-orang terpelajar yang membutuhkan pelatihan sains yang dengan anak-anak sekolah sains dapat memperoleh manfaat dari masukan dari luar dalam mempersepsikan keajaiban dalam menangani. masalah. keberadaan dengan tugas sains.

Pembelajaran sains secara tegas diidentikkan dengan pelatihan Islam. Berbagai hal telah diperjelas oleh Allah 
SWT tentang ilmu pengetahuan, khususnya keajaiban-keajaiban yang terjadi pada Al-Qur'an Al Karim, terhadap arahan manusia agar manusia dapat belajar dan memiliki otak yang lebih luas dalam menyelidiki informasi yang ada di planet ini.

\section{DAFTAR RUJUKAN}

A, M., \& B, P. (t.thn.). Studi Kepustakaan Menganal Landasan Teori dan Praktik Konseling Expresive Writing. BK UNESA, Vol. 8, No 1.

D.A, R. 2002. Al-Qur'an dan Terjemahan. Pena Punda Aksara.

Indra, H. 2009. Pandangan Islam Tentang Ilmu Pengetahuan Dan Refleksinya Terhadap Aktivitas Pendidikan Sains Di Dunia Muslim. Miqot, 248.

Istisaroh. 2017. Ilmu Pengetahuan Alam. Diambil kembali dari Materi Ajar Kelas IV Sekolah Dasar. Dikutip pada 21 Januari 2017: http://istisaroh409.blogspot.com/2

017/01/memahami-gaya-dapatmengubah-gerak-dan.html

M, S. 2020. Penelitian Kepustakaan (Library Research) dalam Penelitian Pendidikan IPA. Natural Science: Jurnal Penelitian Bidang IPA Dan Pendidikan IPA, 41-53. Diambil kembali dari ejournal.uinib.ac.id:

https://ejournal.uinib.ac.id/jurnal/i ndex.php/naturalscience/article/vie w/1555/1159

MS, A. 2018. Pendidikan Sains Dalam Islam. Al-Fatih. Jurnal Pendidikan dan Keislaman, 60.

Mujib, A., \& Muzakir, J. 2008. Ilmu Pendidikan Islam. Jakarta: Kencana.

Nasution, A. 2014. Konsep Dasar Pendidikan Islam. Jurnal Thariqah Ilmiah, 2.

Usman. 2017. Konsep-Konsep Dasar Pendidikan Islam Terpadu. Jurnal Madania, 33-35. 
